\title{
ZNAKOWANIE ŻYWNOŚCI WOLNEJ OD GMO W POLSKIM SYSTEMIE PRAWA ŻYWNOŚCIOWEGO
}

\section{WPROWADZENIE}

Człowiek ma prawo do odpowiedniej żywności, co zapisano w 1948 r. w Powszechnej deklaracji praw człowieka (PDPC) obejmującej prawa osobiste, polityczne, gospodarcze, socjalne i kulturalne ${ }^{1}$, uchwalonej podczas Trzeciej Sesji Ogólnego Zgromadzenia Organizacji Narodów Zjednoczonych (ONZ) w Paryżu. Podobny zapis znalazł się w otwartym do podpisu w $1966 \mathrm{r}$. Międzynarodowym pakcie praw gospodarczych, społecznych i kulturalnych (MPPGSiK)². W 1977 r. Polska ratyfikowała pakt, jak dotąd jednak nie wprowadziła do porządku prawnego pojęcia „prawo do odpowiedniej żywności”. Państwo polskie stworzyło natomiast warunki ustrojowe do jego realizacji ${ }^{3}$. Prawo do odpowiedniej żywności jest mocno związane z kwestią zapewnienia bezpieczeństwa żywnościowego obywatelom, uwarunkowanego bezpieczeństwem żywności. Z uwagi na znaczenie żywności dla zdrowia i życia człowieka oraz z powodów ekonomicznych, rynek rolno-spożywczy w Unii Europejskiej (UE) jest przedmiotem rozbudowanych i relatywnie surowych regulacji prawnych - zajmuje pod tym względem trzecie miejsce po przemyśle samochodowym i chemicznym ${ }^{4}$.

Zgodnie z ramowym rozporządzeniem (WE) nr 178/2002 Parlamentu Europejskiego i Rady z 28 stycznia 2002 r. ustanawiajacym ogólne zasady i wymagania prawa żywnościowego - pierwszym ogólnym celem prawa żywnościowego UE jest zapewnienie wysokiego poziomu ochrony życia i zdrowia ludzkiego, a także interesów ekonomicznych, kulturowych i społecznych konsumenta ${ }^{5}$. Ochronie tej służy odpowiednie informowanie konsumentów na temat spożywanej przez nich żywności, co sprawia, że podejmują oni świadome wybory co do żywności i diety. Rozporządzenie Parlamentu Europejskiego i Rady (UE) nr 1169/2011 z 25 października 2011 r. w sprawie przekazywania konsumentom informacji na temat żywności wymaga jasnego, zrozumiałego i czytelnego etykietowania środków spożywczych, a także zakazuje stosowania informacji, które wprowadzałyby konsumenta w błąd. Prawo konsumenta do rzetelnych

\footnotetext{
1 Kędzia (2018): 5-23.

2 Kowalska (2019): 39-40.

${ }^{3}$ Korzycka, Wojciechowski (2017b): 495-498.

${ }^{4}$ Meulen (2009), podaję za: Taczanowski (2016): 7-9.

${ }^{5}$ Korzycka, Wojciechowski (2017b): 119-140; Taczanowski (2017): 60-68.
} 
informacji na temat żywności wynika także z przepisów ustawy z 23 kwietnia 1964 r. - Kodeks cywilny, gdzie art. $546^{1}$ określa, że jeżeli kupującym jest konsument, sprzedawca jest obowiązany udzielić mu przed zawarciem umowy informacji w języku polskim, wystarczających do prawidłowego i pełnego korzystania z rzeczy sprzedanej. W Polsce większość nieprawidłowości w zakresie oznakowania produktu żywnościowego jest uznawana za zafałszowanie zgodnie z treścią art. 3 ust. 10 ustawy z 21 grudnia 2000 r. o jakości handlowej artykułów rolno-spożywczych (u.j.h.a.r.s.) lub art. 3 ust. 3 pkt 45 ustawy z 25 sierpnia 2006 r. o bezpieczeństwie żywności i żywienia (u.b.ż.ż.) ${ }^{6}$, a kto wprowadza do obrotu artykuły rolno-spożywcze zafałszowane, podlega karze pieniężnej (art. 40a ust. 1 pkt 4 u.j.h.a.r.s.) ${ }^{7}$.

W styczniu 2020 r. do polskiego porządku prawnego weszła w życie ustawa z 13 czerwca 2019 r. o oznakowaniu produktów wytworzonych bez wykorzystania organizmów genetycznie zmodyfikowanych jako wolnych od tych organizmów, co sprawia, że podjęcie badań w tym zakresie jest niezmiernie istotne. Stanowisko UE wobec przekazywania konsumentom informacji na temat żywności zawierającej GMO (genetically modified organisms) jest odmienne niż podejście Stanów Zjednoczonych. W USA przyjęto założenie, że żywność modyfikowana genetycznie nie różni się od żywności konwencjonalnej, a w konsekwencji konsument nie musi być informowany o wykorzystaniu GMO podczas produkcji żywności. W przeciwieństwie do regulacji amerykańskiej prawo UE odrębnie reguluje żywność genetycznie zmodyfikowaną i daje konsumentowi możliwość dokonywania samodzielnego wyboru żywności różniącej się zastosowaniem inżynierii genetycznej ${ }^{8}$.

Celem pracy jest określenie istoty znakowania żywności i pasz w odniesieniu do wykorzystania GMO podczas ich wytwarzania. W artykule dokonano analizy dogmatycznej przepisów ustawy z 13 czerwca 2019 r. o oznakowaniu produktów wolnych od GMO na tle odpowiednich regulacji prawa UE. W opracowaniu zastosowano następujące metody badawcze: analizę aktów normatywnych, analizę źródeł literaturowych, analizę dokumentów wtórnych (sprawozdań, raportów).

\section{PROBLEMY STOSOWANIA INŻYNIERII GENETYCZNEJ DO PRODUKCJI ŻYWNOŚCI I PASZ}

W ustawie z 22 czerwca 2001 r. o organizmach genetycznie zmodyfikowanych (u.o.g.z.) przez organizm genetycznie zmodyfikowany (GMO) rozumiany jest organizm inny niż ludzki, w którym materiał genetyczny został zmieniony w sposób niezachodzacy w warunkach naturalnych wskutek krzyżowania lub naturalnej rekombinacji. W inżynierii genetycznej naukowcy rozrywaja struk-

\footnotetext{
${ }^{6}$ Kowalska (2019): 196.

7 Kowalska, Kowalski (2018): 339-350; Kowalska, Soon, Manning (2018): 348-356.

8 Korzycka, Wojciechowski (2017a): 465-488.
} 
tury DNA, wycinaja geny jednego gatunku i wklejają je do drugiego (np. geny zwierząt do gatunków roślinnych, dzięki czemu te ostatnie nabywają pewne właściwości wykorzystanych gatunków zwierząt). Jest to możliwe dzięki uniwersalnemu ,językowi genów” - kodowi genetycznemu, który ma tę samą konstrukcję dla każdego gatunku zwierząt, roślin i mikroorganizmów. Kod DNA zawiera instrukcje działań żywej komórki ${ }^{9}$. Rozwój nauki, a głównie biotechnologii i inżynierii genetycznej, doprowadził do uzyskania możliwości tworzenia nowych organizmów (przede wszystkim nowych odmian roślin, a także zwierząt), w których materiał genetyczny jest zmieniany w sposób niezachodzący w warunkach naturalnych głównie po to, aby jak najefektywniej alokować zasoby tkwiace w rolnictwie i gospodarce żywnościowej.

Uprawa roślin transgenicznych ${ }^{10}$ dla celów komercyjnych na świecie miała swój początek w latach dziewięćdziesiątych XX w. ${ }^{11}$ Od tego czasu powierzchnia upraw GMO rosła bardzo dynamicznie w wielu regionach świata, w latach 1996-2017 wzrosła 114 razy (z 1,66 mln ha do 189,8 $\mathrm{mln}$ ha) ${ }^{12}$. Największa powierzchnia upraw GMO znajduje się w USA, Brazylii i Argentynie. Coraz większe jest zainteresowanie uprawami GMO w krajach rozwijających się (Indie, Pakistan, Boliwia, Sudan, Wietnam, Honduras, Bangladesz itd.) ${ }^{13}$. Światowy rynek roślin GMO zdominowały uprawy soi, bawełny, kukurydzy i rzepaku; w 2015 r. 48\% powierzchni upraw tych roślin na świecie stanowiły uprawy $\mathrm{GMO}^{14}$, przy czym sa to rośliny wykorzystywane do celów nieżywnościowych (bioenergia, tkaniny, leki) oraz do produkcji żywności i pasz. Modyfikacje genetyczne służyły najczęściej dwóm celom: 1) zwiększeniu odporności roślin na herbicydy (rolnicy mogą stosować większe ilości tych środków, gdyż rośliny ze zmienionym kodem genetycznym nie giną od nich, co może stwarzać nowe zagrożenia dla ekosystemu); 2) zwiększeniu odporności roślin na szkodniki (zastosowanie technologii Bt powinno przekładać się na wyższe plony z jednostki powierzchni oraz mniejsze zużycie chemicznych środków ochrony roślin, a to z kolei na wzrost dochodów producentów rolnych, zmniejszenie presji na zajmowanie nowych obszarów pod uprawy czy poprawę stanu wyżywienia $)^{15}$. Zwolennicy GMO pisza, że dzięki większej odporności roślin uprawnych na choroby i szkodniki stosuje się mniejszą ilość pestycydów, a w konsekwencji mniej gazów cieplarnianych będzie uwalnianych do atmosfery ${ }^{16}$; koszty produkcji mogą się zmniejszyć; dzięki GMO można szybko zalesić kolejne obszary; GMO pozwoli wyżywić więcej ludzi na świecie; zmniejszy się skala strat w łańcuchu dostaw; taniej można wyprodukować bioenergię czy leki. Jak dotąd nie stwierdzono jednoznacznie negatywnego wpływu żywności zawierającej GMO

\footnotetext{
${ }^{9}$ Kurek (2009): 27-41.

10 Rośliny transgeniczne to rośliny, których DNA zostało zmodyfikowane metodami inżynierii genetycznej.

11 Kaphengst et al. (2011): 1.

12 ISAA (2017).

13 ISAA (2017).

14 Brookes, Barfoot (2017): 117-147.

15 Tamże; Kurek (2009): 33-39.

16 Brookes, Barfoot (2017): 117.
} 
na zdrowie człowieka ${ }^{17}$, choć sugeruje się, że ujemny wpływ żywności/ pasz GMO może ujawnić się w następnych pokoleniach (m.in. w obniżonej płodności kolejnych populacji zwierząt i ludzi). Natomiast przeciwnicy obawiają się zaburzenia naturalnego ładu w przyrodzie, twierdza, że nie jest możliwa koegzystencja upraw modyfikowanych oraz konwencjonalnych, a tym bardziej ekologicznych. Kolejnym argumentem jest fakt, że organizmy zmienione będą się mnożyć i mutować, co może spowodować nieoczekiwane skutki. Kompromisem w sporze o GMO jest między innymi wprowadzenie przepisów o znakowaniu żywności „z GMO” oraz „bez GMO”, co daje konsumentowi wybór.

\section{UNIJNE REGULACJE PRAWNE W ZAKRESIE WYKORZYSTYWANIA, ETYKIETOWANIA I MOŻLIWOŚCI ŚLEDZENIA RUCHU GMO W LAŃCUCHU DOSTAW}

Kształt polskich przepisów prawnych odnoszących się do organizmów genetycznie modyfikowanych zależy od ustawodawstwa unijnego w tym zakresie ze względu na obowiązek harmonizacji krajowego prawa z wymogami UE. Pierwsze unijne dyrektywy w tym obszarze zostały przyjęte w 1990 r., przy czym stanowisko Komisji Europejskiej oraz poszczególnych państw członkowskich wobec wprowadzania do obrotu żywności i pasz wyprodukowanych przy użyciu GMO zmieniało się w czasie, i nadal nie jest spójne ${ }^{18}$. Postępujący rozwój biotechnologii i inżynierii genetycznej oraz rosnąca dezaprobata krajów UE wobec dotychczasowych działań mających na celu zagwarantowanie bezpieczeństwa żywności spowodowały zmiany w prawie UE dotyczącym GMO.

Obecnie kluczowe znaczenie dla kwestii korzystania z organizmów modyfikowanych genetycznie mają następujące przepisy prawa unijnego:

1) dyrektywa Parlamentu Europejskiego i Rady 2001/18/WE z 12 marca $2001 \mathrm{r}$. w sprawie zamierzonego uwalniania do środowiska organizmów zmodyfikowanych genetycznie i uchylająca dyrektywę Rady 90/220/EWG;

2) rozporządzenie (WE) nr 1829/2003 Parlamentu Europejskiego i Rady z 22 września 2003 r. w sprawie genetycznie zmodyfikowanej żywności i paszy;

3) dyrektywa Parlamentu Europejskiego i Rady (UE) 2015/412 z 11 marca 2015 r. w sprawie zmiany dyrektywy 2001/18/WE w zakresie umożliwienia państwom członkowskim ograniczenia lub zakazu uprawy organizmów zmodyfikowanych genetycznie (GMO) na swoim terytorium;

4) rozporządzenie (WE) nr 1830/2003 dotyczące możliwości śledzenia i etykietowania organizmów zmodyfikowanych genetycznie (GMO) oraz możliwości śledzenia żywności i produktów paszowych wyprodukowanych z GMO;

5) dyrektywa Parlamentu Europejskiego i Rady 2009/41/WE z 6 maja 2009 r. w sprawie ograniczonego stosowania mikroorganizmów zmodyfikowanych genetycznie.

17 Brzóska (2019); Snell et al. (2012): 1134-1148.

18 Stępień (2017): 157-168. 
W dyrektywie 2001/18/WE ważną rolę przypisano kwestii jawności rejestrów żywności i pasz zawierających GMO oraz udziału społeczeństwa w podejmowaniu decyzji w myśl zasady przejrzystości. Produkty znajdujące się w Unijnym Rejestrze Genetycznie Zmodyfikowanej Żywności i Paszy moga znajdować się na rynku UE, pod warunkiem że są oznakowane zgodnie z przepisami rozporządzenia (WE) nr 1829/2003. Zgodnie z art. 13 tego rozporządzenia na etykiecie produktu spożywczego, który zawiera lub składa się z GMO, jest wyprodukowany lub zawiera składniki wyprodukowane z GMO powinna być zamieszczona jedna $\mathrm{z}$ następujących informacji: „genetycznie zmodyfikowany”, „wyprodukowany z genetycznie zmodyfikowanego (nazwa składnika)”, „zawiera genetycznie zmodyfikowany (nazwa organizmu)”, „zawiera (nazwa składnika) wyprodukowany z genetycznie zmodyfikowanego (nazwa organizmu)". Dla produktów spożywczych nieopakowanych jednostkowo, oferowanych konsumentowi końcowemu lub w miejscach zbiorowego żywienia (stołówkach, szpitalach, restauracjach itp.), informacja o tym, że dany produkt spożywczy jest genetycznie zmodyfikowany, musi znajdować się przy produkcie w miejscu widocznym dla konsumenta. Z obowiązku znakowania zwolnione sa produkty zawierające GMO na poziomie nieprzekraczającym 0,9\% (składników rozważanych osobno lub pojedynczego składnika), pod warunkiem że obecność ta jest niezamierzona lub nieunikniona ze względów technicznych. $\mathrm{W}$ innym przypadku znakowanie jest obowiązkowe.

Dyrektywa (UE) 2015/412 ustanowiła klauzulę opt-out, która daje możliwość państwom członkowskim, aby po wprowadzeniu określonej uprawy GMO na rynek UE, mogły indywidualnie decydować o tym, czy ograniczyć lub zakazać określonej uprawy bez wskazania przyczyn naukowych. Zapewnienie większej swobody krajom UE w tym zakresie przełożyło się na ograniczenie upraw GMO w tych krajach, gdyż aż 19 państw, w tym Polska, zadeklarowało skorzystanie z klauzuli opt-out, a 16 państw poinformowało o wprowadzeniu całkowitego zakazu ${ }^{19}$. Polska jest krajem postrzeganym jako przeciwnik stosowania GMO w uprawie roślin i hodowli zwierząt.

Rozporządzenie (WE) nr 1830/2003 wymaga, aby kraje UE podejmowały środki w celu zapewnienia możliwości śledzenia i etykietowania dopuszczonych organizmów genetycznie zmodyfikowanych na wszystkich etapach wprowadzania ich do obrotu. Celem śledzenia przepływu paszy lub żywności w łańcuchu dostaw jest poprawa efektywności działań podejmowanych w przypadku wystapienia zagrożenia bezpieczeństwa żywności ${ }^{20}$. Informacje gromadzone w ramach funkcjonowania systemu śledzenia wyrobów pozwalaja sprawnie zarządzać akcją ewentualnego wycofania wyrobów z rynku ${ }^{21}$. Już w art. 18 rozporządzenia (WE) nr 178/2002 zobowiązano przedsiębiorców sektora spożywczego do zapewnienia możliwości prześledzenia drogi surowców i produktów w całym łańcuchu zaopatrzenia w żywność. W rozporządzeniu nie określono jednak szczegółów dotyczących informacji (ich zakresu, minimalne-

19 Zapała (2016): 105-121.

20 Bezat, Jarzębowski (2011): 75-84.

21 Dabbene, Gay (2011): 139-146; Dabbene, Gay, Tortia (2014): 65-80. 
go czasu przechowywania itd.), które mają być zbierane i przechowywane przez przedsiębiorstwa sektora spożywczego i pasz. W art. 5 rozporządzenia (WE) nr 1830/2003 określono zatem zakres informacji przekazywanych na piśmie do podmiotu gospodarczego otrzymującego produkt GMO oraz ustanowiono wymóg dysponowania systemami i znormalizowanymi procedurami umożliwiającymi przechowywanie tych informacji przez okres pięciu lat po każdej transakcji.

Wyrazem tego, że coraz bardziej dostrzega się wpływ wykorzystywania GMO w rolnictwie i hodowli na środowisko naturalne, jest publikacja następujacych dokumentów: dyrektywa Komisji (UE) 2018/350 z 8 marca 2018 r. zmieniająca dyrektywę Parlamentu Europejskiego i Rady 2001/18/WE w odniesieniu do oceny ryzyka organizmów zmodyfikowanych genetycznie dla środowiska naturalnego; decyzja Wykonawcza Komisji (UE) 2018/1790 z 16 listopada 2018 r. uchylająca decyzję 2002/623/WE ustanawiającą noty wyjaśniające w sprawie oceny zagrożenia ekologicznego przeprowadzanej dla organizmów zmodyfikowanych genetycznie.

Efektem transpozycji rozbudowanego systemu regulacji UE dotyczących GMO było uchwalenie u.o.g.z. Zagadnienia wykorzystywania GMO w odniesieniu do żywności ujęto w u.b.ż.ż., kwestię zaś stosowania GMO w żywieniu zwierzat uregulowano w ustawie z 22 lipca 2006 r. o paszach. Na podstawie przepisów u.o.g.z. funkcjonują: Rejestr Zakładów Inżynierii Genetycznej, Rejestr Zamkniętego Użycia GMO, Rejestr Zamierzonego Uwalniania GMO do Środowiska, Rejestr Produktów GMO. Dostęp do nich jest bezpłatny i powszechny, co zapewnia realizację zasady jawności rejestrów sformułowaną w dyrektywie 2001/18/WE. Jednym z podstawowych obowiązków wynikajacych z treści u.o.g.z. jest obowiązek oznakowania produktów zawierających GMO.

\section{ZASADY OGÓLNE OZNAKOWANIA ŻYWNOŚCI I PASZ JAKO WOLNYCH OD ORGANIZMÓW GENETYCZNIE ZMODYFIKOWANYCH W POLSKIM SYSTEMIE PRAWNYM}

W czerwcu 2019 r., po przeszło dwóch latach od rozpoczęcia, zostały zakończone prace parlamentu nad ustawą o oznakowaniu produktów wytworzonych bez wykorzystania organizmów genetycznie zmodyfikowanych jako wolnych od tych organizmów (dalej: ustawa) ${ }^{22}$. W uzasadnieniu projektu ustawy zaakcentowano, że opracowanie przepisów umożliwiających oznakowanie produktów wolnych od GMO było wynikiem postulatów zgłaszanych przez organizacje społeczne, organizacje konsumenckie i czesść producentów ${ }^{23}$. Ponadto funkcjonujące od kilku lat regulacje dotyczące znakowania żywności wolnej

${ }^{22}$ Zob. <https://www.gov.pl/web/rolnictwo/znakowanie-produktow-bez-gmo> [dostęp: 25.11.2019]; $<$ https://legislacja.rcl.gov.pl/projekt/12297951> [dostęp: 25.11.2019].

${ }^{23}$ Zob. <https://www.sejm.gov.pl/Sejm8.nsf/druk.xsp?nr=3262> [dostęp: 31.03.2020]. 
od GMO w Niemczech, Francji czy Austrii powodowały, że te same produkty sprzedawane w tych krajach oraz w Polsce były różnie oznakowane. Przyjęcie odmiennych rozwiązań ograniczało zatem swobodny przepływ towarów na terytorium UE.

W ślad za ustawą Minister Rolnictwa i Rozwoju Wsi na podstawie upoważnienia przewidzianego w ustawie wydał rozporządzenie z 4 listopada 2019 r. w sprawie znaków graficznych, które stosuje się w celu oznakowania żywności i pasz jako wolnych od organizmów genetycznie zmodyfikowanych. Na dzień 1 grudnia 2019 r. jest to jedyne rozporządzenie wykonawcze do omawianej ustawy.

Zgodnie z ustawa, przepisy w niej zawarte zaczęły obowiązywać z dniem 1 stycznia 2020 r. Okres 6 miesięcznej vacatio legis, przewidziany w ustawie jest znacznie dłuższy od standardowego 14-dniowego, wskazanego w art. 4 ustawy z 20 lipca 2000 r. o ogłaszaniu aktów normatywnych i niektórych innych aktów prawnych. Określenie tak odległego terminu wejścia w życie ustawy może wynikać między innymi z faktu nałożenia nowych uprawnień i obowiązków na organy urzędowej kontroli żywności oraz producentów żywności i pasz. Ustawodawca prawdopodobnie uznał, że jest to optymalny czas dla obu grup podmiotów na przygotowanie i wdrożenie zmian pozwalających na prawidłowe wykonanie zapisów ustawy.

Ustawa składa się z 15 artykułów. Przepisy art. 1 określają problematykę prawna, której ustawa dotyczy. W pierwszej części ustawy określono zasady znakowania żywności i pasz. Druga grupa przepisów dotyczy obowiązków ciążących na podmiotach wprowadzających na rynek żywność lub pasze oznakowane jako wolne od GMO. Trzecia grupa obejmuje zagadnienia związane z przeprowadzaniem kontroli przestrzegania przepisów ustawy. Ostatni zbiór przepisów, ściśle powiązany z poprzednim, określa sankcje związane z naruszeniem przepisów ustawy. W art. 2 ustawy znajdziemy wyłączenia jej stosowania (tj. rodzaje żywności i pasz, w odniesieniu do których nie znajduje zastosowania). Zgodnie z treścią art. 2 ustawa nie ma zastosowania do żywności i pasz wyprodukowanych lub wprowadzonych do obrotu w innym państwie UE zgodnie z prawem tego państwa, a także wyprodukowanych w państwie członkowskim Europejskiego Porozumienia o Wolnym Handlu (EFTA), będącym stroną umowy o Europejskim Obszarze Gospodarczym (EOG) albo wyprodukowanych lub wprowadzonych do obrotu w Republice Turcji.

W art. 3-5, tworzacych pierwszą część przepisów, ustawodawca określił, że znakowana może być żywność pochodzenia zwierzęcego i roślinnego oraz pasze. Ponadto ustawa $\mathrm{w}$ art. 3 ust. 2 wprowadza możliwość znakowania produktów pochodzenia zwierzęcego, nawet gdy u zwierząt, z których lub od których został pozyskany ten produkt, były zastosowane wytworzone z GMO produkty lecznicze weterynaryjne, materiały paszowe, dodatki paszowe lub pomoce przetwórcze. Ustawodawca przewiduje również możliwość znakowania żywności w sytuacji, gdy żywność taka zawiera, składa się lub została wyprodukowana z GMO wpisanego do właściwego rejestru. Dopuszcza się jej oznakowanie jako wolnej od GMO, gdy: 
a) zawartość modyfikacji genetycznej w tym GMO wynosi nie więcej niż 0,1\%,

b) obecność GMO w tej żywności jest przypadkowa lub nieunikniona technicznie.

Ponadto art. 4 ust. 2 przewiduje możliwość znakowania żywności jako wolnej od GMO, nawet gdy były zastosowane wytworzone z GMO lub za ich pomoca, niedostępne w innej formie, dodatki do żywności lub substancje pomagające w przetwarzaniu.

Ustawa w art. 5 stanowi, że oznakowanie żywności i pasz jako wolnych od GMO jest dobrowolne. W tym miejscu należy wskazać, że ustawodawca wprowadził dwa rodzaje znakowania. Pierwsze oznaczenie to „Bez GMO”, które odnosi się do żywności pochodzenia roślinnego, a także żywności składającej się z więcej niż jednego składnika, w skład której nie wchodzi produkt pochodzenia zwierzęcego oraz do pasz. Drugie oznaczenie „Wyprodukowano bez stosowania GMO” jest przeznaczone dla produktów pochodzenia zwierzęcego i żywności składającej się z więcej niż jednego składnika, w skład której wchodzi produkt pochodzenia zwierzęcego ${ }^{24}$. Oznaczenie takie powinno znajdować się na opakowaniu lub etykiecie, a także w dokumentacji towarzyszacej tej żywności lub paszy. Szczegóły dotyczące samego oznaczenia uregulowane zostały w rozporządzeniu wykonawczym do ustawy.

Zgodnie z rozporządzeniem z 2019 r. w sprawie znaków graficznych stosowanych dla żywności i pasz wolnych od GMO obydwa znaki składają się z koła podzielonego poziomo na dwa odcinki, przy czym górny odcinek koła jest w kolorze białym, a dolny jego odcinek jest w kolorze zielonym i zawiera rysunek trzech złączonych ze sobą liści w kolorze białym. Znaki w zależności od rodzaju żywności lub paszy, na której mają się znaleźć, różnią się użytymi sformułowaniami. W rozporządzeniu przewidziano możliwość ich sporządzania w kolorze białym na czarnym tle oraz w kolorze czarnym na białym tle (rysunek 1).

\section{Rysunek 1}

Wzory znaków graficznych stosowanych do oznakowania żywności i pasz wolnych od GMO
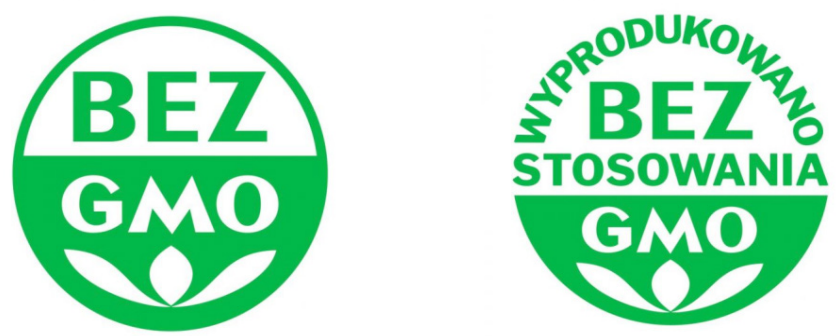

Źródło: Załącznik do rozporządzenia Ministra Rolnictwa i Rozwoju Wsi z 4 listopada 2019 r. w sprawie znaków graficznych, które stosuje się w celu oznakowania żywności i pasz jako wolnych od organizmów genetycznie zmodyfikowanych.

${ }^{24}$ Zob. <https://ijhars.gov.pl/news/items/wolne-od-gmo-znaki-graficzne.html> [dostęp: 25.11.2019]. 


\section{OBOWIĄZKI PODMIOTÓW WPROWADZAJĄCYCH NA RYNEK ŻYWNOŚĆ LUB PASZE OZNAKOWANE JAKO WOLNE OD GMO}

Przechodząc do drugiej grupy przepisów określonych w art. 7, należy podkreślić, że zakres obowiązków, jakie muszą zostać spełnione przez podmioty wprowadzające na rynek żywność pochodzenia roślinnego, żywność pochodzenia zwierzęcego albo pasze, został określony w zbliżony sposób.

Podmioty te podlegają obowiązkowi przeprowadzania badań laboratoryjnych na obecność modyfikacji genetycznych w żywności lub paszy lub składnikach użytych do jej produkcji. Ponadto zobowiązane sa posiadać i przechowywać przez okres dwóch lat od wprowadzenia na rynek dokumenty dotyczące żywności lub paszy. Dokumenty musza pozwolić:

a) na weryfikację, czy żywność ta lub składniki użyte do jej produkcji spełniają warunki określone w art. 3 ust. 1 pkt 2 i ust. 4 pkt 1 (w przypadku żywności pochodzenia zwierzęcego - art. 3 ust. 1 pkt 1 oraz ust. 2 i 5 , w przypadku pasz - art. 3 ust. 3 i ust. 4 pkt 2), w tym zawierające wyniki badań laboratoryjnych na obecność modyfikacji genetycznych w tej żywności lub składnikach użytych do jej produkcji;

b) określić procedury opracowane na podstawie analizy zagrożenia wystapienia modyfikacji genetycznych, wskazujące częstotliwość pobierania próbek żywności lub składników użytych do jej produkcji do badań laboratoryjnych, o których mowa w lit. a, w celu potwierdzenia spełnienia wyżej wymienionych warunków.

Warte uwagi jest dopuszczenie możliwości stosowania oznaczenia „wolne od GMO” na produktach roślinnych, które posiadaja swoje odpowiedniki wpisane do Unijnego Rejestru Genetycznie Zmodyfikowanej Żywności i Paszy prowadzonego przez Komisję Europejska. Gdyby wprowadzono możliwość stosowania takiego oznaczenia na produktach pochodzenia roślinnego, które nie mają takich odpowiedników, konsument zostałby wprowadzony w błąd co do tego, że w obrocie znajdują się produkty zmodyfikowane, a brak modyfikacji genetycznej wyróżnia je wśród innych.

Ustawodawca przewidział wyjątki od przeprowadzania obowiązkowych badań laboratoryjnych. W przypadku pasz i składników użytych do jej produkcji, sytuacja taka zachodzi wtedy, gdy:

- w wyniku przetworzenia nie jest możliwe wykrycie obecności modyfikacji genetycznej,

- przeprowadzona analiza zagrożenia wystapienia modyfikacji genetycznych wykazała brak takiego zagrożenia,

- składniki pozyskane do produkcji paszy zostały pozyskane z roślin wyprodukowanych z materiału siewnego w rozumieniu art. 3 ust. 1 pkt 8 ustawy z 9 listopada 2012 r. o nasiennictwie, odmian gatunków roślin uprawnych niezmodyfikowanych genetycznie,

- żywność lub pasza są oznakowane jako wolne od GMO.

$\mathrm{Z}$ analogiczną sytuacją mamy do czynienia w odniesieniu do żywności pochodzenia roślinnego. Ustawodawca do katalogu zawierającego wyłączenia od 
obowiązku przeprowadzania badań laboratoryjnych dołączył również żywność pochodzenia roślinnego oraz pasze sprzedawane luzem przez podmiot, który wprowadza na rynek tę żywność w ramach obrotu detalicznego. Należy zauważyć, iż nie zwalnia się producentów żywności pochodzenia zwierzęcego od przeprowadzania badań laboratoryjnych. Warto dodać, że w prawie żywnościowym UE w sposób szczególny traktuje się mięso i jego produkty ze względu na kryzys związany z BSE, dioksynami i innymi głośnymi skandalami żywnościowymi.

\section{ZASADY PRZEPROWADZANIA KONTROLI}

Trzecia grupa przepisów reguluje zagadnienia związane z prowadzaniem kontroli. Artykuł 9 ustawy nakłada na Głównego Inspektora Jakości Handlowej Artykułów Rolno-Spożywczych (Główny Inspektor) i Prezesa Urzędu Ochrony Konkurencji i Konsumentów (Prezes UOKiK) obowiązek sporządzania rocznych programów kontroli podmiotów wprowadzających na rynek żywność i pasze oznakowane jako wolne od GMO oraz obowiązek sporządzania rocznych raportów z kontroli. Obowiązek każdorazowego sporządzenia rocznego programu kontroli przestrzegania przepisów, zgodnie z ustawa, powinien zostać spełniony do dnia 30 grudnia roku poprzedzajacego rok przeprowadzenia kontroli. Wyjątek od tej zasady został określony w art. 13, z którego wynika, że program kontroli na rok 2020 sporządza się w terminie 3 miesięcy od dnia wejścia w życie ustawy. Skoro zaś ustawa zaczęła obowiązywać z dniem 1 stycznia 2020 r., to termin ten upłynął z dniem 31 marca $2020 \mathrm{r}$. Z kolei termin na sporządzenie rocznego raportu $\mathrm{z}$ kontroli przestrzegania przepisów ustalony został na 30 kwietnia roku następujacego po roku, w którym kontrole przestrzegania przepisów ustawy zostały przeprowadzone. Co ciekawe, nie określono sytuacji, gdy wskazane organy administracji nie wykonuja w terminie nałożonych na nie obowiązów lub wykonaja je po upływie ustawowych terminów. Przepisy nie wymieniaja elementów, jakie mają zawierać roczne plany kontroli. Ustawodawca zdecydował się enumeratywnie określić niezbędne informacje, jakie ma zawierać roczny raport z przeprowadzonych kontroli, czyli: liczbę przeprowadzonych kontroli, liczbę skontrolowanych podmiotów i rodzaje działalności wykonywanej przez te podmioty, rodzaj skontrolowanych produktów, liczbę i rodzaj stwierdzonych nieprawidłowości, liczbę wydanych zaleceń pokontrolnych oraz liczbę i rodzaj nałożonych sankcji. Ponadto przepisy ustawy nakładaja na Głównego Inspektora obowiązek przedkładania właściwemu ministrowi corocznych raportów z przeprowadzonych kontroli przestrzegania przepisów ustawy. Współpraca pomiędzy Głównym Inspektorem a Prezesem UOKiK, zgodnie z przepisami ustawy, odbywać się będzie na mocy porozumienia. $\mathrm{Na}$ dzień 28 listopada 2019 r. takie porozumienie nie zostało zawarte. 


\section{ODPOWIEDZIALNOŚĆ ZA NARUSZENIE PRZEPISÓW USTAWY}

W odniesieniu do ostatniej grupy regulacji, dotyczących sankcji związanych z nieprzestrzeganiem przepisów trzeba wskazać, że katalog kar obejmuje sankcje o charakterze finansowym. W ocenie autorów jest to jedyny skuteczny rodzaj kary. Kary pieniężne wydawane są w formie decyzji administracyjnej Wojewódzkiego Inspektora Inspekcji Handlowej lub powiatowego lekarza weterynarii w sytuacji, gdy kontrola dotyczy pasz; Wojewódzkiego Inspektora Jakości Handlowej Artykułów Rolno-Spożywczych albo Wojewódzkiego Inspektora Inspekcji Handlowej w sytuacji, gdy kontrola dotyczy żywności.

Przy określaniu wysokości kary, brany jest pod uwagę stopień szkodliwości czynu, zakres naruszenia, dotychczasowa działalność podmiotu i wielkość jego obrotów oraz przychodu, a także wartość kontrolowanych produktów. Co ciekawe, przed ustaleniem i nałożeniem kary, podmiot prowadzący kontrolę może zażądać od kontrolowanego dokumentów niezbędnych do ustalenia okoliczności mających wpływ na jej wysokość. Warto zaznaczyć, że kary pieniężne nakładane na podmioty nieprzestrzegające przepisów ustawy pełnią funkcje prewencyjne i represyjne, a także stanowią dochód budżetu państwa. Kara powinna być wystarczająco dotkliwa, aby odstraszyć przedsiębiorców od prowadzenia nieuczciwych praktyk w przyszłości.

Ustawa różnicuje wysokość nakładanych kar w zależności od rodzaju stwierdzonego naruszenia. Za niezgodne z przepisami oznakowanie pasz ustawodawca przewiduje karę pieniężną w wysokości do dziesięciokrotnej wartości korzyści majątkowej uzyskanej lub która mogłaby zostać uzyskana przez wprowadzenie paszy na rynek, ale nie niższej niż $2000 \mathrm{zł}$. W przypadku pozostałych naruszeń przewidzianych w ustawie, to jest braku obowiązkowych badań, braku dokumentacji albo nieprzechowywania dokumentacji przez czas wskazany w ustawie, przepisy przewidują karę w wysokości do czterdziestokrotnego przeciętnego wynagrodzenia w gospodarce narodowej za rok poprzedzający rok nałożenia kary, ogłaszanego przez Prezesa Głównego Urzędu Statystycznego. Kara taka nie może być niższa niż 4000 zł.

W przypadku żywności ustawa przewiduje kary za brak obowiązkowych badań, brak dokumentacji albo nieprzechowywanie dokumentacji przez określony czas. Gdy naruszenie zostanie stwierdzone, wysokość kary jest określana w sposób analogiczny do przypadku pasz. Dodatkowo, zarówno w przypadku żywności, jak i pasz, ustawodawca przewidział kary za uniemożliwianie i utrudnianie przeprowadzenia kontroli. Wysokość tych kar nie może przekroczyć czterdziestokrotnego przeciętnego wynagrodzenia $\mathrm{w}$ gospodarce narodowej za rok poprzedzajacy, przy czym ustawa nie określa minimalnej ich wysokości.

Ciekawostką pozostaje fakt, że w przypadku naruszenia przepisów przez skontrolowany podmiot, który nie uzyskał przychodu w roku rozliczeniowym poprzedzającym rok nałożenia kary pieniężnej, ustawa przewiduje możliwość nałożenia kary. Kara w takiej sytuacji może być nałożona w wysokości niższej niż 4000 zł, ale nie niższej niż 2000 zł. 


\section{DYSKUSJA NA TEMAT OZNAKOWANIA ŻYWNOŚCI I PASZ TYPU „Z GMO” I „BEZ GMO”}

Wprowadzenie nowych znaków graficznych miało na celu ujednolicenie informacji o specyfice produktów, czyli braku modyfikacji genetycznej w żywności pochodzenia roślinnego i w paszach oraz braku stosowania modyfikacji genetycznej w procesie wytwarzania żywności pochodzenia zwierzęcego (przede wszystkim o niestosowaniu pasz GMO w żywieniu zwierząt). Przekazanie rzetelnej, jednoznacznej i łatwej w odbiorze informacji konsumentowi ma służyć podejmowaniu przez niego świadomych wyborów i wpływa na poziom ochrony jego zdrowia, życia i interesów ekonomiczno-społecznych. Można nawet uznać, iż takie oznakowanie pełni funkcję edukacyjną i marketingową. Przekaz ma pozytywny wydźwięk i może skłonić nabywcę żywności do tego, aby głębiej zastanowił się nad dokonywanym wyborem.

Istnieje wyraźna różnica między „oznakowaniem pozytywnym” żywności i pasz typu „bez GMO” a „oznakowaniem negatywnym” typu „genetycznie zmodyfikowany”. Niektórzy autorzy twierdza, że pierwsze oznaczenie ma za zadanie zmanipulowanie konsumenta i sprawienie, aby wybrał dany produkt, drugie zaś stygmatyzuje niejako towar i odwodzi konsumenta od jego naby$\mathrm{cia}^{25}$. Argumenty za i przeciw oznakowaniu pozytywnemu i negatywnemu żywności i pasz w obszarze wykorzystania GMO zestawiono w tabeli 1 .

Tabela 1

Cechy różnicujące oznakowania żywności i pasz typu „z GMO” i „bez GMO”

\begin{tabular}{|l|l|}
\hline \multicolumn{1}{|c|}{ „z GMO” } & \multicolumn{1}{c|}{ „bez GMO” } \\
\hline Negatywny wydźwięk & Pozytywny wydźwięk \\
\hline Obowiązkowe oznaczenie & Dobrowolne oznaczenie \\
\hline $\begin{array}{l}\text { Ponoszenie dodatkowych kosztów przez } \\
\text { producentów zwiazanych ze znakowaniem } \\
\text { żywności i pasz GMO }\end{array}$ & $\begin{array}{l}\text { Sugerowanie, że produkt ma szczególne } \\
\text { właściwości }\end{array}$ \\
\hline
\end{tabular}

Źródło: opracowanie własne na podstawie Hansen (2004): 67-76.

Już wcześniej prowadzono dyskusje na temat wprowadzenia oznaczenia „może zawierać GMO” zamiast „zawiera GMO”. Uznano jednak, że sformułowanie „może zawierać” nie informuje konsumenta o cechach produktu $\mathrm{w}$ stopniu wystarczajacym ${ }^{26}$. Powstaje pytanie, czy to uczciwe wobec wszystkich uczestników rynku, aby wymagać od producentów oznakowania żywności zawierającej GMO, a jednocześnie nie wymagać oznakowania żywności bez GMO. Mimo że producenci wykorzystujący GMO ponoszą dodatkowe koszty

\footnotetext{
25 Jackson (2000): 319-330.

${ }^{26}$ Hansen (2004): 67-76.
} 
związane z oznaczaniem swoich produktów wynikające chociażby z kontrowersji i negatywnych skojarzeń związanych ze stosowaniem inżynierii genetycznej, to fakt, że prawo do informacji jest dziśs podstawą ochrony konsumenta-nieprofesjonalisty, uzasadnia decyzję ustawodawcy. Konsument żywności jest najsłabszym ogniwem w łańcuchu dostaw ze względu na posiadane zasoby (w tym zasoby wiedzy, infrastrukturę czy środki finansowe). Nie jest on w stanie ocenić bezpieczeństwa środka spożywczego ani jego wrażliwości na zepsucie, składu czy zastosowanych metod wytwarzania. Prawdopodobnie można uznać, że każda informacja przekazana konsumentowi, każdy znak graficzny nosi znamiona manipulacji. Podstawowe znaczenie ma natomiast prawda, konsument nie może być wprowadzany w błąd. Prawdziwe, jasne i zrozumiałe informacje na etykiecie żywności pomagają konsumentowi świadomie decydować o tym, czy akceptuje w diecie swojej i własnej rodziny produkty zawierające GMO, np. ze względu na satysfakcjonująca relację ceny do jakości środka spożywczego. Oba oznaczenia wskazane w tabeli 1 wpływają na ocenę jakości produktu przez konsumenta oraz sprzyjają segmentacji rynku. Na jakość żywności wpływają dwie perspektywy: obiektywna, o której decyduje spełnienie wymagań, oraz subiektywna, odczuwana przez konsumenta ${ }^{27}$. Znakowanie żywności tworzy tę jakość w obydwu wspomnianych wymiarach. Warto nadmienić, że immanentną cechą dynamicznie rozwijającego się kapitalizmu były i są ciagłe zmiany sposobów produkcji i konsumpcji na całym świecie ${ }^{28}$. Wprowadzone oznaczenia produktów z GMO i wolnych od GMO wychodzą tym zmianom naprzeciw. Oznakowanie żywności w tym zakresie służy zapewnieniu wiarygodności żywności przeznaczonej dla wegetarian i wegan, alergików oraz osób, które ze względów religijnych nie spożywają określonych środków spożywczych (np. mięsa wieprzowego).

\section{ZAKOŃCZENIE}

Odmienne podejście rządów do wykorzystywania inżynierii genetycznej $\mathrm{w}$ rolnictwie i hodowli w dobie globalizacji i postępujacej liberalizacji handlu sprawia, że informacja przekazywana konsumentowi w zakresie stosowania GMO ma zasadnicze znaczenie dla zapewnienia wysokiego poziomu jego ochrony. Można uznać, że oznakowanie służy budowaniu zaufania między konsumentami a producentami żywności, które jest podważane we wszystkich rejonach świata przez skandale żywnościowe ${ }^{29}$, szybko wychodzace na światło dzienne za sprawą globalnych mediów. Konsument jest ostatecznym adresatem żywności i ponosi całe ryzyko konsekwencji zdrowotnych, związanych z jej spożyciem, oraz konsekwencji ekonomicznych, związanych z jej nabyciem $^{30}$. Do podstawowych praw konsumenta należą: prawo do bezpieczeń-

\footnotetext{
27 Wiśniewska (2015): 16-17.

28 Paruzel (2018): 334-346.

29 Kowalczyk (2015): 2-64.

30 Ozimek (2012): 61-70.
} 
stwa nabywanego produktu i prawo do informacji. Znakowanie żywności jest narzędziem gwarantujacym prawidłową realizację konstytucyjnego prawa konsumenta do informacji ${ }^{31}$. Rzetelna, jasna, zrozumiała i wyczerpujacca informacja przekazana konsumentom na temat żywności stanowi punkt wyjścia działań mających na celu zapewnienie wysokiego poziomu ochrony jego życia, zdrowia i interesów ekonomiczno-kulturowych; informacja ta jest podstawa podejmowania świadomych decyzji przez nabywcę żywności.

Produkcja żywności zawierającej GMO ma wielu przeciwników, a także licznych zwolenników. Kierują się oni własnym sumieniem, przekonaniami, względami ekonomicznymi, społecznymi, kulturowymi, środowiskowymi. Oznaczenia „z GMO” i „bez GMO” od lat wywołują dyskusję wśród badaczy, przedstawicieli rządów, menadżerów oraz nieprofesjonalistów. Na skutek tej debaty oraz $\mathrm{w}$ efekcie transpozycji systemu regulacji UE dotyczących GMO uchwalono ustawę z 13 czerwca 2019 r. o oznakowaniu produktów wolnych od GMO i wydano pierwsze rozporządzenie wykonawcze do tej ustawy, w którym wprowadzono dwa znaki graficzne: „Bez GMO” i „Wyprodukowano bez zastosowania GMO". Miało to na celu ujednolicenie informacji o specyfice produktów wolnych od GMO, która stanowi jasny przekaz dla polskich konsumentów. Rolą ustawy jest także ograniczenie nadużywania oznaczeń „Bez GMO” i „Wyprodukowano bez zastosowania GMO" przez nierzetelnych producentów, co ma znaczenie dla zapewnienia warunków uczciwej konkurencji. Kolejne prace badawcze mogłyby zostać poświęcone zachowaniom konsumentów na rynku żywności wytworzonej z wykorzystaniem GMO i bez GMO w Polsce oraz analizie zmian w prawie regulującym zagadnienia GMO, a także odbiór tych zmian w społeczeństwie (wśród producentów i konsumentów żywności).

\author{
Aleksandra Kowalska \\ Uniwersytet Marii Curie-Sktodowskiej w Lublinie \\ aleksandra.kowalska@umcs.lublin.pl \\ https://orcid.org/0000-0003-3854-951X \\ Jarostaw Kowalski \\ Uniwersytet Marii Curie-Sktodowskiej w Lublinie \\ jaroslaw.kowalski@poczta.umcs.lublin.pl \\ https://orcid.org/0000-0002-4731-1928
}

Bezat, A., Jarzębowski, S. (2011). Traceability w łańcuchu dostaw przetwórstwa spożywczego. Logistyka 2: 75-84.

Brookes, G., Barfoot, P. (2017). Environmental impacts of genetically modified (GM) crop use 1996-2015: Impacts on pesticide use and carbon emissions. GM Crops \& Food 8(2): 117-147.

Brzóska, F. (2016). Skutki żywieniowe i zdrowotne stosowania pasz GMO w żywieniu zwierząt. Warszawa. <http://izbozpasz.pl/pluginAppObj/pluginAppObj_96_04/skutki.pdf> [dostęp: 26.11.2019].

Dabbene, F., Gay, P. (2011). Food traceability systems: performance evaluation and optimization. Computers and Electronics in Agriculture 75(1): 139-146.

\footnotetext{
31 Żuchowska-Grzywacz (2019): 229-243.
} 
Dabbene, F., Gay, P., Tortia, C. (2014). Traceability issues in food supply chain management: a review. Biosystems Engineering 120: 65-80.

Hansen, K. (2004). Does autonomy count in favor of labeling genetically modified food? Journal of Agricultural and Environmental Ethics 17(1): 67-76.

ISAA (2017). Brief 53: Global Status of Commercialized Biotech/GM Crops: 2017: Biotech Crop Adoption Leads to Greater Sustainability and Socioeconomic Opportunities for Global Farmers and Citizens. <http://www.isaaa.org/resources/publications/briefs/53/default.asp> [dostęp: 27.11.2019].

Jackson, D. (2000). Labeling products of biotechnology: toward communication and consent. Journal of Agricultural and Environmental Ethics 12(3): 319-330.

Kaphengst, T., El Benni, N., Evans, C., Finger, R., Herbert, S., Morse, S., Stupak, N. (2011). Assessment of the economic performance of GM crops worldwide. Report of the European Commission. $<$ https://ec.europa.eu/food/sites/food/files/plant/docs/gmo_rep-stud_2011_report_econ-perf.pdf> [dostęp: 27.11.2019].

Kędzia, Z. (2018). 70 lat Powszechnej Deklaracji Praw Człowieka - pomnik czy żywy dokument? Ruch Prawniczy, Ekonomiczny i Socjologiczny 81(4): 5-23.

Korzycka, M., Wojciechowski, P. (2017a). Regulacja prawna żywności genetycznie zmodyfikowanej w USA i UE w kontekście planowanego Transatlantyckiego Porozumienia Handlowo-Inwestycyjnego (TTIP). Studia Iurdica Lublinensia 26(1): 465-488.

Korzycka, M., Wojciechowski, P. (2017b). System prawa żywnościowego. Warszawa.

Kowalczyk, S. (2015). Wzrost turbulencji na rynku globalnym a bezpieczeństwo, [w:] R. Sobiecki (red.), Przeciwdziałanie turbulencjom w gospodarce. Warszawa: 2-64.

Kowalska, A. (2019). Ekonomiczne problemy fałszowania żywności. Instrumenty przeciwdziałania. Lublin.

Kowalska, A., Kowalski, J. (2018). Administrative Liability Related to Food Fraud. A case of Poland, [w:] S. Kapounek, V. Kočiš Krůtilová (eds.), 21st Annual International Conference Enterprise and Competitive Environment. Conference proceedings. Brno: 339-350.

Kowalska, A., Soon, J.M., Manning, L. (2018). A study on adulteration in cereals and bakery products from Poland. Food Control 92: 348-356.

Kurek, A. (2009). Rolnictwo ekologiczne czy inżynieria genetyczna? [w:] E. Bojar, K. Pylak (red.), EkoLubelszczyzna XXI wieku. Podnoszenie świadomości o żywności ekologicznej mieszkańców regionu. Lublin-Toruń: 27-41.

Meulen, B.M.J. van der (2009). European Food Law Handbook. Wageningen.

Ozimek, I. (2012). Ochrona konsumentów na rynku żywności - wybrane aspekty. Konsumpcja i Rozwój 1: 61-70.

Paruzel, R. (2018). Problem innowacji - ujęcie teoretyczne. Przegląd Prawno-Ekonomiczny 2(43): 334-346.

Snell, C., Bernheim, A., Bergé, J.B., Kuntz, M., Pascal, G., Paris, A., Ricroch, A.E. (2012). Assessment of the health impact of GM plant diets in long-term and multigenerational animal feeding trials: a literature review. Food and Chemical Toxicology 50(3/4): 1134-1148.

Stępień, M. (2017). Analiza regulacji prawnych w zakresie wykorzystania GMO. Przegląd Prawa i Administracji 108(3759): 157-168.

Taczanowski, M. (2016). Definicje legalne prawa żywnościowego - przyczyny tworzenia i formy. Żywność. Nauka. Technologia. Jakość 6(103): 7-9.

Taczanowski, M. (2017). Prawo żywnościowe. Warszawa.

Wiśniewska, M.Z. (2015). Systemowe zarządzanie obroną żywności przed terroryzmem. Gdańsk.

Zapała, C. (2016). Prawne aspekty obrotu żywnością genetycznie modyfikowaną w Unii Europejskiej i Polsce. Studenckie Zeszyty Naukowe 19(30): 105-121.

Żuchowska-Grzywacz, M. (2019). Znakowanie produktów żywnościowych jako narzędzie gwarantujące prawidłową realizację konstytucyjnego prawa konsumenta do informacji. Przegląd Prawa Konstytucyjnego 49(3): 229-243. 


\section{LABELING NON-GMO FOODS IN THE POLISH FOOD LAW SCHEME}

\section{$\mathrm{Su} \mathrm{m} \mathrm{m}$ a r y}

The research problem addressed in this work is the labeling of GMO-free food. The main aim of the paper is to determine the essence of food and feed labeling regarding the use of GMO. An analysis of the Polish Act of 13 June 2019 on the Labeling of Products Produced without the Use of Genetically Modified Organisms, and thus being free from such organisms, is performed in the context of the EU food law. The following research methods were applied in the course of the research: an analysis of national and EU legislation, an analysis of the subject literature, and an analysis of secondary documents (statements, reports). Food labeling provides a basis for consumers to make informed choices and is crucial for ensuring a high level of protection of human life, health, and socio-economic interests. The unification of information on the specificity of non-GMO products in the new law makes the message transparent and clear, which may have implications for stronger confidence among business and consumers.

Keywords: GMO; food law; labeling of food 